\title{
Attitudes About Remarriage in Malta
}

\author{
ANGELA ABELA and CLAIRE CASHA \\ Department of Family Studies, University of Malta, Msida, Malta \\ MANWEL DEBONO \\ Centre for Labour Studies, University of Malta, Msida, Malta \\ MARY ANNE LAURI \\ Department of Psychology, University of Malta, Msida, Malta
}

\begin{abstract}
This study investigated the attitudes about remarriage of married and previously married Maltese people. Respondents were selected using stratified random sampling; 810 men and 1,196 women answered a questionnaire by means of computer-assisted telephone interviewing. The majority (67.4\%) of respondents did not consider remarriage. Remarriage was more likely to be considered by respondents who were younger, previously married, nonparents, had children who were not all born within marriage, and were of higher socioeconomic status. The study highlights the differences in attitude according to gender and marital status. The fact that pro-remarriage attitudes were endorsed by $32.6 \%$ of respondents and that these were more likely to come from nontraditional family forms suggests that family life in Malta is no longer dictated by normative social imperatives. The need for the legal protection of families headed by cohabiting partners is highlighted.
\end{abstract}

KEYWORDS attitudes, Malta, remarriage

Remarriage is a common occurrence in many different cultures across the world. Until recently, however, the Maltese could only remarry if their spouse passed away, if they succeeded in obtaining a divorce from abroad, or if they had their marriage declared null by the Catholic Church. Divorce was legalized by the Maltese Parliament in July 2011 following a consultative

Address correspondence to Angela Abela, Department of Family Studies, University of Malta, Old Humanities Building, Room 243, Msida, Malta. E-mail: angela.abela@um.edu.mt 
referendum in May 2011 in which 52.67\% of the electorate pronounced itself in favor of the introduction of divorce legislation (Abela, 2013).

This study was carried out shortly before the May 2011 referendum. The main research question sought to elicit attitudes toward remarriage from the population of married people and those who were previously married.

\section{CONCEPTUAL FRAMEWORK}

Bronfenbrenner's (1994) ecological systems theory, which takes into account five environmental contexts, is adopted here as a conceptual framework for understanding attitudes about remarriage. Three of these contexts-namely the microsystem, the macrosystem, and the chronosystem-are particularly pertinent to our study. On a microsystem level, children not only influence the stages of reconnecting with others and with a partner (Steenbergen Richmond, 2000) and the selection of a new partner (Määttä \& Uusiautti, 2012), but can also pressure parents to marry (Goode, cited in Rose and Price-Bonham, 1973).

On a macrosystem level, culture plays an important part. Kavas (2010) reported that for some highly educated, divorced women in Turkey, remarriage offered comfort in a society anxious over divorced women, despite stigma toward remarriage. Divorce and remarriage decisions also take place in the wider context of social and historical time (Schmiege, Richards, \& Zvonkovic, 2001) and this relates to what Bronfenbrenner (1994) termed chronosystem influences. As a case in point, the influence of the Catholic Church in Malta is waning (Abela, 2013) but marrying in church remains popular (Galea, 2012). As Kim (2011) pointed out, the psychological cost of divorce may be higher for Roman Catholics because the Catholic Church preaches against divorce and sanctions only church marriages. In addition, Ahituv and Lerman (2004) reported that Catholic status lowers entry into remarriage.

\section{LITERATURE REVIEW}

Although there is research on the demographics of people who remarry, there is a dearth of research about reasons for and against remarriage, especially with regard to remarriage after divorce. A gap in knowledge of how older adults make decisions about remarriage was reported by Watson, Bell, and Stelle (2010). Furthermore, most literature on reasons for and against remarriage is qualitative. We have not come across studies conducted among members of the general public exploring attitudes toward remarriage. Because of this gap in the literature, most of the literature review in this article focuses on people who actually remarried rather than on the attitudes 
about remarriage of those who had not yet gone through such an experience, as was the case for our respondents.

The literature search was carried out by searching for the following key phrases: "attitudes about/towards remarriage/re-marriage," "reasons for/against remarriage/re-marriage," "decision/intent to remarry/re-marry," and "more/less likely to remarry/re-marry" on the University of Malta's e-library Social Science databases, Social Science Research Network, and Google Scholar search engines.

Men are more likely to remarry, and remarry sooner, than women (McGoldrick \& Carter, 2013). Higher education raises rates of remarriage (Ahituv \& Lerman, 2004; Cruz, 2012). The likelihood of remarriage is also linked to economic stability: The employed are more likely to remarry than those looking for a job (de Jong Gierveld, 2004) and changing jobs lowers the likelihood of remarriage (Ahituv \& Lerman, 2004). There are, however, gender differences: Women with higher resources in the form of more income and education are less likely to remarry, whereas the reverse is true for their male counterparts, who are more likely to remarry, and sooner (McGoldrick \& Carter, 2013). This relates to economic theories of remarriage that are often linked to the remarriage of women.

The proportion of individuals who remarry declines with age (Cruz, 2012). This might, in turn, explain why remarriage is more common among individuals who are younger at the time of separation. Although children are generally believed to reduce remarriage prospects (De Graaf \& Kalmijn, 2003), findings around parity for both genders are mixed and nuanced (see, e.g., Bzostek, McLanahan, \& Carlson, 2012; Földházi, 2010; Lunn \& Fahey, 2011; Miner \& Shackelford, 2010; Schmiege et al., 2001).

\section{Reasons for Remarriage}

Attitudes about remarriage are inextricably linked to the benefits gained. Committed companionship that helps overcome loneliness is one of the many psychological benefits conferred by remarriage. This was reported as a major reason for remarriage by participants in the studies of Kavas (2010) and Schmiege et al. (2001). It is consistent with Wilcox and Nock's (2006) argument that emotional needs have emerged as paramount in contemporary marriages.

A prevalent theme emanating from Kavas's (2010) study was the expression of preference for marriage over single life, although this was linked to different meanings. For some, marriage related to a more "disciplined life," whereas for others it related to being "a real family." Määttä and Uusiautti (2012) reported that the formalization of a new relationship through marriage restored balance and normalcy. Some women in Kavas's (2010) study also mentioned bearing children as a leading reason for wanting to remarry. 
In the study by Kavas (2010), some of those who had remarried talked about love as having been the main driver behind their decision to remarry. Others attributed their decision to remarry to their desire to have a complete family with a father figure for their children. As mentioned previously, the need to overcome loneliness was also highlighted. According to Määttä and Uusiautti (2012), this increased the appreciation of a new marriage. Participants in the studies by Kavas (2010) and Määttä and Uusiautti (2012) also gave positive accounts of their remarriage experience, and spoke of its positive effects on emotional healing and self-esteem.

Kavas (2010) reported that women's emotional needs superseded economic and social imperatives. This could relate to the fact that her participants were highly educated women. An alternative possibility is that economic needs are not articulated as reasons for remarriage. Schmiege et al. (2001) assessed a number of quantitative factors to test their hypothesis that women who became single parents at a younger age, had more children, and had less education would be more likely to remarry. This hypothesis was supported on a quantitative level but not supported by the qualitative part of the study at face value, as only 3 out of the 43 women who had remarried discussed the financial benefits of having a marital partner. At the same time, however, those who had a failed remarriage did discuss financial irresponsibility on the part of the former spouse, leading the authors to presume that this provided subtle evidence of the possibility of remarriage as an economic survival strategy for some single mothers and that the influence of economic advantages of marriage on women's decisions might occur at an unarticulated level.

\section{Reasons Against Remarriage}

Määttä and Uusiautti (2012) discussed how losing an intimate relationship results in losing something of oneself, and memories of a bruising love leave many divorcees in their study yearning for love and concomitantly avoiding new relationships due to the fear of getting hurt. The authors referred to the common statement of "having enough of men." Distrust of men was the primary theme among divorcees in Kavas's study (2010) who did not consider remarriage, although some women in her study also expressed distrust of marriage as an institution, with one challenging the perception of remarriage as a life course event. The second main reason cited by the women in Kavas's study for their position was a major fear of putting their children through emotional turmoil.

Steenbergen Richmond (2000) also reported on fears about remarriage: The participants in her study cited the fear of repeating past mistakes as one of the reasons they did not want to remarry. The author posited that it might have been difficult for participants to make themselves vulnerable once again in the context of the effect of their marriages and ensuing divorces. Many 
participants in her study had discussed the idea of remarriage with their partners and concluded there were no advantages of remarriage. Their stance was attributable to not seeing the benefits of remarriage as well as apprehension in the face of uncertainty about whether it would last or a fear that remarriage would deteriorate their relationship. Doubts about the chances of success for second marriage given the huge risks implied from the very beginning were also reported by Määttä and Uusiautti (2012).

\section{METHOD}

This article studies the attitudes of Maltese people toward remarriage. To study the research question quantitatively, the best data collecting tool in terms of time and financial resources was the questionnaire. Researchers wanted to study the differences in the attitudes held by two specific groups of people-a group of married people and another group of previously married people-for purposes of comparing attitudes. The latter included separated and divorced people as well as those whose marriage had been declared null.

\section{Data Collecting Tool}

The questionnaire was made up of 11 closed-ended questions. Questions 1 to 6 were demographic questions. Questions 7 and 8 asked about the respondent's children, and Question 9 was the main question, which asked "If divorce is introduced in Malta and you decide to divorce, would you consider remarrying?" (in Maltese, "Jekk f'Malta jidћol id-divorzju u tiddeciedi li tiddi-

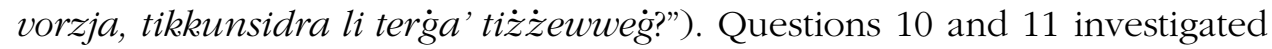
the reasons respondents gave for their reply.

\section{Sample}

The sample was chosen from the population of individuals who were married or previously married as reported in the National Statistics Office (NSO) database based on the national census held in 2005. The sample was selected using stratified random sampling. The stratification was done by gender, age, and district of residence. A total of 2,840 persons were contacted by trained interviewers. Respondents were equally divided between men and women residing in various towns and villages in Malta. To enable analysis of data, the residences were categorized into six districts and occupations were categorized into 10 groups. 


\section{Field Work}

Data were collected by means of computer-assisted telephone interviewing (CATI) between March 16 and March 24, 2011. Biases were actively considered and addressed. The CATI system uses computers to handle the administrative and other functions associated with interviewing such as sample management, quota control, call disposition monitoring, productivity reporting, and interviewer monitoring. The data entry program had a number of built-in validations so that skip patterns are executed exactly as intended while responses were ensured to be within a specific range. In addition, constant supervision during the data collection stage guaranteed a harmonized data collection process.

\section{Response Rate}

Of the persons contacted, 2,006 responded (70.6\%). This response rate was considered very high compared to other surveys and this is probably due to the fact that at the time of the survey, divorce was a hot issue and was at the very top of the public agenda. People wanted to give their opinion and be heard. The sample consisted of 810 men (40.4\%) and 1,196 women (59.6\%). The average age of male respondents was 54 years and that of female respondents was 50 years. Of the respondents, $53.1 \%$ were married, $42.7 \%$ were separated, $3.1 \%$ had had their marriages annulled, and $1.1 \%$ were divorced. In terms of their level of education, $49.1 \%$ of the respondents had a secondary level of education, $25.4 \%$ had a postsecondary or tertiary level of education, and $25.5 \%$ had a primary level of education or no schooling at all. With regard to occupational status, 23.8\% of the respondents worked in professional or managerial occupations, $17.9 \%$ worked in technical jobs, $17.1 \%$ worked in service and sales jobs, $10.5 \%$ had clerical jobs, $10.5 \%$ worked in craft and related trades jobs, and 10.4\% worked in elementary occupations.

Previously married respondents were significantly younger than married respondents (averaging 50 and 54 years, respectively). An independentsamples $t$ test showed that the difference between the two groups was statistically significant, $t(2003)=6.663, p<.001$, two-tailed, equality of variances not assumed.

\section{Data Analysis}

Descriptive and inferential statistics about the relationships among the most relevant variables were derived through the Predictive Analytics SoftWare Statistics (PASW Version 18.0). Inferential statistics were carried out through chi-square analyses. 


\section{RESULTS}

\section{Consideration of Remarriage}

The main question in this study asked: "If divorce is introduced in Malta and you decide to divorce, would you consider remarrying?" The majority of the respondents, $67.4 \%$, answered that they would not consider remarriage if divorce was introduced in Malta, whereas only $18.1 \%$ said they would (see Table 1).

Chi-square analyses were performed to assess potential relationships between this assertion and nine demographic characteristics: gender, age,

TABLE 1 Consideration of Remarriage

\begin{tabular}{|c|c|c|c|c|c|c|}
\hline & $\begin{array}{l}\text { Yes } \\
(\%)\end{array}$ & $\begin{array}{l}\text { No } \\
(\%)\end{array}$ & $\begin{array}{c}\text { Unsure } \\
(\%)\end{array}$ & $N$ & $P$ & $\begin{array}{c}\text { Cramer's } \\
V\end{array}$ \\
\hline Total & 18.1 & 67.4 & 14.5 & 2,006 & & \\
\hline \multicolumn{7}{|l|}{ Gender } \\
\hline Male & 20.2 & 66.5 & 13.2 & \multirow{2}{*}{2,006} & .09 & \multirow[t]{2}{*}{.049} \\
\hline Female & 16.7 & 68.0 & 15.3 & & & \\
\hline \multicolumn{7}{|l|}{ Age bracket } \\
\hline$<40$ years & 30.2 & 50.0 & 19.8 & \multirow[t]{3}{*}{2,006} & $130.31^{* * *}$ & \multirow[t]{3}{*}{.180} \\
\hline 41-60 years & 18.3 & 67.0 & 14.7 & & & \\
\hline $61+$ years & 7.3 & 83.3 & 9.4 & & & \\
\hline \multicolumn{7}{|l|}{ Marital status } \\
\hline Married & 11.0 & 71.3 & 17.7 & \multirow{2}{*}{2,006} & $86.18^{* * *}$ & \multirow[t]{2}{*}{.207} \\
\hline Previously married & 26.2 & 63.0 & 10.7 & & & \\
\hline \multicolumn{7}{|l|}{ Parenthood } \\
\hline Yes & 16.6 & 68.9 & 14.5 & \multirow[t]{2}{*}{2,006} & $43.46^{* * *}$ & \multirow[t]{2}{*}{.147} \\
\hline No & 38.1 & 48.3 & 13.6 & & & \\
\hline \multicolumn{7}{|l|}{ Children within marriage only } \\
\hline Yes & 13.8 & 71.3 & 14.8 & \multirow[t]{2}{*}{1,859} & $104.59^{* * *}$ & \multirow[t]{2}{*}{.237} \\
\hline No & 45.1 & 43.8 & 11.1 & & & \\
\hline \multicolumn{7}{|l|}{ Educational attainment } \\
\hline Up to secondary level & 15.6 & 70.6 & 13.8 & \multirow[t]{2}{*}{2,006} & $31.14^{* * *}$ & \multirow[t]{2}{*}{.125} \\
\hline Postsecondary/tertiary level & 25.5 & 58.0 & 16.5 & & & \\
\hline \multicolumn{7}{|l|}{ Employment status } \\
\hline Active & 25.2 & 59.1 & 15.7 & \multirow{2}{*}{2,006} & $60.55^{* * *}$ & \multirow{2}{*}{.174} \\
\hline Inactive & 12.7 & 73.9 & 13.5 & & & \\
\hline \multicolumn{7}{|l|}{ Occupation } \\
\hline Senior officials/managers/professionals & 34.4 & 53.1 & 12.4 & \multirow[t]{2}{*}{877} & $12.86^{* *}$ & \multirow[t]{2}{*}{.121} \\
\hline Other occupations & 22.3 & 60.9 & 16.8 & & & \\
\hline \multicolumn{7}{|l|}{ District } \\
\hline Southern Harbour & 16.5 & 70.0 & 13.5 & \multirow[t]{6}{*}{ 2, 006} & 15.86 & \multirow[t]{6}{*}{.063} \\
\hline Northern Harbour & 18.1 & 68.7 & 13.2 & & & \\
\hline South Eastern & 17.9 & 66.9 & 15.3 & & & \\
\hline Western & 13.0 & 68.9 & 18.1 & & & \\
\hline Northern & 22.7 & 61.9 & 15.5 & & & \\
\hline Gozo and Comino & 25.0 & 62.5 & 12.5 & & & \\
\hline
\end{tabular}

Note. $N=$ number of participants; $P=$ Pearson chi-square.

${ }^{* *} p<.01 .{ }^{* * *} p<.001$. 
marital status, parenthood, whether all children were born within marriage, educational attainment, employment status, type of occupation, and district.

No significant relationship was found between gender and the consideration of remarriage, $\chi^{2}(2, N=2,006)=4.91, p=.09$, Cramer's $V=$ .049 . Indeed, the majority of both men and women would not consider remarrying $(66.5 \%$ and $68.0 \%$, respectively). However, previously married respondents were significantly more likely to consider remarriage when compared to married respondents, $\chi^{2}(2, N=2,006)=86.18, p<.001$, Cramer's $V=.207$; with $26.2 \%$ of previously married respondents and a much lower $11.0 \%$ of married respondents considering remarriage. Previously married men were statistically more likely to consider remarriage than previously married women $\left(32.9 \%\right.$ and $22.5 \%$, respectively), $\chi^{2}(2, N=941)=14.91$, $p=.001$, Cramer's $V=.126$.

There was a significant relationship between age and consideration of remarriage, $\chi^{2}(4, N=2,006)=130.31, p<.001$, Cramer's $V=.180$. The younger the respondents were, the greater the likelihood of responding positively to the main question of this study. Whereas nearly a third (30.2\%) of the respondents aged 40 years or younger would consider remarriage, the percentage dropped down to 7.3\% among persons 61 years or older. Previously married persons aged 40 or younger were the most likely group to consider remarriage $(40.9 \%), \chi^{2}(10, N=2,006)=219.375, p<.001$, Cramer's $V=.234$.

Parents were statistically less likely to consider remarriage than nonparents $\left(16.6 \%\right.$ and $38.1 \%$, respectively), $\chi^{2}(2, N=2,006)=43.46, p<.001$, Cramer's $V=.147$. At $45.8 \%$, previously married respondents without children were the most likely group to consider remarriage, whereas married respondents with children were the least likely $(9.9 \%), \chi^{2}(6, N=2006)=$ $124.35, p<.001$, Cramer's $V=.176$. Whether or not all children were born within marriage was also related to parents' opinion toward remarriage, $\chi^{2}(2$, $N=1,859)=104.59, p<.001$, Cramer's $V=.237$. Parents whose children were not all born within marriage were considerably more likely to be in favor of remarriage when compared to those whose children were all born within marriage ( $45.1 \%$ and $13.8 \%$, respectively). Besides, out of the parents with children born outside marriage, those with children from the current partner were more likely to be in favor of remarriage than those without children from the current partner (57.8\% and 31.6\%, respectively), $\chi^{2}(2, N=$ $162)=17.962, p<.001$, Cramer's $V=.33$.

Educational attainment was significantly related to the consideration of remarriage, $\chi^{2}(2, N=2,006)=31.14, p<.001$, Cramer's $V=.125$. Those who had a lower level of educational attainment (up to secondary school) were less likely to answer positively when compared to those with a postsecondary or tertiary level of education ( $15.6 \%$ and $25.5 \%$, respectively). There were no significant gender differences in the consideration of remarriage within the same educational attainment category. Men and women with a 
postsecondary or tertiary level of education were similar in their consideration of remarriage, $\chi^{2}(2, N=510)=.22, p=.896$, Cramer's $V=.021$, as were men and women with a lower educational attainment level, $\chi^{2}(2, N=$ $1,496)=4.54, p=.103$, Cramer's $V=.055$.

The relationship between employment status and consideration of remarriage was significant, $\chi^{2}(2, N=2,006)=60.55, p<.001$, Cramer's $V=.174$. Persons who were economically active tended to consider more the possibility of remarriage than those who were inactive (25.2\% and $12.7 \%$, respectively). Besides, the type of occupation was also significantly related to consideration of remarriage, $\chi^{2}(2, N=877)=12.86, p<.01$, Cramer's $V=$ .121. Senior officials, managers, and professionals were more likely to consider remarriage than respondents in other occupations (34.4\% and 22.3\%, respectively).

There was no statistically significant difference with regard to attitudes about remarriage among the six Maltese districts, $\chi^{2}(10, N=2,006)=15.86$, $p=.10$, Cramer's $V=.06$.

\section{Reasons for Considering Remarriage}

The respondents who would consider remarriage were asked to come up with reasons for their assertion. As can be seen in Table 2, the three most common reasons for considering remarriage were: love (chosen by 38.2\% of respondents), to live in the company of someone (23.9\%), and because it's a right (23.9\%). To have rights and entitlements was chosen by another $12.9 \%$ of respondents. Fewer persons would consider remarriage to enhance the commitment of the present relationship (8.8\%), due to their belief in marriage or the family $(8.5 \%)$, for the sake of children $(8.0 \%)$, or for other reasons $(4.9 \%)$.

Chi-square analyses were carried out to assess potential relationships between the reasons for considering remarriage and gender. Male and female

TABLE 2 Reasons for Considering Remarriage by Gender

\begin{tabular}{lrrrrr}
\hline & & Male & Female & \multicolumn{2}{c}{ Cramer's } \\
& Total & $\%$ & $\%$ & $P$ & $V$ \\
\hline Love & 38.2 & 31.1 & 44.0 & $6.36^{*}$ & .132 \\
To live in the company of someone & 23.9 & 26.2 & 22.0 & .88 & .049 \\
To have rights and entitlements & 12.9 & 13.4 & 12.5 & .07 & .014 \\
For the sake of the children & 8.0 & 4.9 & 10.5 & $3.88^{*}$ & .103 \\
To enhance commitment of present relationship & 8.8 & 10.4 & 7.5 & .92 & .050 \\
Because it's everyone's right & 23.9 & 25.0 & 23.0 & .20 & .023 \\
Believe in marriage/family & 8.5 & 7.9 & 9.0 & .13 & .019 \\
Other reasons & 4.9 & 6.7 & 3.5 & 1.97 & .074 \\
\hline
\end{tabular}

Note. $N=364 . P=$ Pearson chi-square.

${ }^{*} p<.05$. 
TABLE 3 Reasons for Considering Remarriage by Marital Status

\begin{tabular}{lcccc}
\hline & $\begin{array}{c}\text { Married } \\
\%\end{array}$ & $\begin{array}{c}\text { Previously } \\
\text { married \% }\end{array}$ & $P$ & \multicolumn{2}{c}{ Cramer's } \\
\hline Love & 35.0 & 39.7 & .72 & .045 \\
To live in the company of someone & 36.8 & 17.8 & $15.66^{* * *}$ & .207 \\
To have rights and entitlements & 7.7 & 15.4 & $4.18^{*}$ & .107 \\
For the sake of the children & 3.4 & 10.1 & $4.86^{*}$ & .116 \\
To enhance commitment of present relationship & 5.1 & 10.5 & 2.89 & .089 \\
Because it's everyone's right & 23.9 & 23.9 & 0.00 & .000 \\
Believe in marriage/family & 5.1 & 10.1 & 2.54 & .084 \\
Other reasons & 6.8 & 4.0 & 1.31 & .060 \\
\hline
\end{tabular}

Note. $N=364 . P=$ Pearson chi-square.

${ }^{*} p<.05 .{ }^{* * *} p<.001$.

respondents expressed similar levels of agreement with most of the listed reasons. However, significant relationships were found between gender and two reasons, namely love and for the sake of the children. Female respondents were more likely to consider remarriage for love when compared to men, $\chi^{2}(1, N=364)=6.36, p<.05$, Cramer's $V=.132$. Female respondents were also more likely to consider remarriage for the sake of the children when compared to men, $\chi^{2}(1, N=364)=3.88, p<.05$, Cramer's $V=.103$.

Married and previously married persons also expressed some different reasons for considering remarriage (see Table 3). Married respondents were more likely to justify remarriage on the basis of wanting to live in the company of someone, $\chi^{2}(1, N=364)=15.66, p<.001$, Cramer's $V=.207$. On the other hand, previously married respondents were significantly more likely to consider remarrying to have rights and entitlements, $\chi^{2}(1, N=364)$ $=4.18, p<.05$, Cramer's $V=.107$, and for the sake of the children, $\chi^{2}(1$, $N=364)=4.86, p<.05$, Cramer's $V=.116$.

\section{Reasons for Not Considering Remarriage}

The respondents who stated that they would not consider remarriage were asked to specify the reasons for this assertion. The three most common reasons were religious or social beliefs and values (chosen by 20.3\% of respondents), not to relive past bad experiences (19.6\%), and old age or health (18.9\%; see Table 4). Other reasons such as burden of marriage process/marriage, marriage doesn't make sense/don't believe in marriage, and reasons relating to children were given much less prominence (and were chosen by $2.7 \%, 4.9 \%$, and $5.8 \%$ of the respondents, respectively).

Chi-square analyses were performed to assess potential relationships between the reasons for not considering remarriage and gender. Male and female respondents expressed similar levels of agreement on 7 of the 10 categories of reasons for not considering remarriage. Female respondents were 
TABLE 4 Reasons for Not Considering Remarriage by Gender

\begin{tabular}{lrrrrr}
\hline & & Males & Females & & Cramer's \\
& Total & $\%$ & $\%$ & $P$ & $V$ \\
\hline Not to relive past bad experiences & 19.6 & 15.8 & 22.1 & $8.35^{* *}$ & .079 \\
Not to have any commitment & 11.2 & 11.3 & 11.2 & .01 & .002 \\
There is no particular personal need & 12.9 & 14.1 & 12.2 & 1.06 & .028 \\
Religious or social beliefs and values & 20.3 & 18.0 & 21.8 & 2.86 & .046 \\
Old age or health & 18.9 & 24.7 & 15.1 & $19.24^{* * *}$ & .119 \\
Marriage doesn't make sense/don't believe & 4.9 & 4.1 & 5.4 & 1.24 & .030 \\
$\quad$ in marriage & & & & & .028 \\
There should be only one marriage in life & 7.4 & 6.5 & 8.0 & 1.07 & .030 \\
Burden of marriage process/marriage & 2.7 & 3.3 & 2.3 & 1.22 & .059 \\
Reasons relating to children & 5.8 & 4.1 & 6.9 & $4.70^{*}$ & .002 \\
Other reasons & 12.0 & 12.1 & 11.9 & .01 & \\
\hline
\end{tabular}

Note. $N=1,352 . P=$ Pearson chi-square.

${ }^{*} p<.05 .{ }^{* *} p<.01{ }^{* * *} p<.001$.

TABLE 5 Reasons for Not Considering Remarriage by Marital Status

\begin{tabular}{lcccc}
\hline & Married & Previously & & Cramer's \\
& $\%$ & married $\%$ & $P$ & $V$ \\
\hline Not to relive past bad experiences & 10.4 & 31.4 & $92.79^{* * *}$ & .262 \\
Not to have any commitment & 9.4 & 13.7 & $6.18^{*}$ & .068 \\
There is no particular personal need & 10.8 & 15.7 & $7.03^{* *}$ & .072 \\
Religious or social beliefs and values & 23.2 & 16.5 & $9.14^{* *}$ & .082 \\
Old age or health & 20.9 & 16.4 & $4.57^{*}$ & .058 \\
Marriage doesn't make sense/don't believe & 4.2 & 5.7 & 1.65 & .035 \\
$\quad$ in marriage & & & & .096 \\
There should be only one marriage in life & 9.6 & 4.6 & $12.47^{* * *}$ & .096 \\
Burden of marriage process/marriage & 3.3 & 2.0 & 2.02 & .039 \\
Reasons relating to children & 5.9 & 5.6 & 0.08 & .008 \\
Other reasons & 13.6 & 9.9 & $4.14^{*}$ & .055 \\
\hline
\end{tabular}

Note. $N=1,352 . P=$ Pearson chi-square.

${ }^{*} p<.05 .{ }^{* *} p<.01 .{ }^{* * *} p<.001$.

significantly more likely than male respondents not to reconsider remarriage not to relive past bad experiences, $\chi^{2}(1, N=1,352)=8.35, p<.01$, Cramer's $V=.079$ and for reasons relating to children, $\chi^{2}(1, N=1,352)=4.70, p<$ .05 , Cramer's $V=.059$. On the other hand, male respondents were more likely than female respondents not to reconsider remarriage due to old age or health, $\chi^{2}(1, N=1,352)=19.24, p<.001$, Cramer's $V=.119$.

Married and previously married persons also expressed some different reasons for not considering remarriage (see Table 5). Previously married respondents were statistically more likely not to consider remarriage not to relive past bad experiences, $\chi^{2}(1, N=1,352)=92.79, p<.001$, Cramer's $V=.262$, because they saw no particular personal need, $\chi^{2}(1, N=1,352)$ $=7.03, p<.01$, Cramer's $V=.072$, and because they did not want to have any commitment, $\chi^{2}(1, N=1,352)=6.18, p<.05$, Cramer's $V=.068$. 
On the other hand, they were less likely to state that there should be only one marriage in life, $\chi^{2}(1, N=1,352)=12.47, p<.001$, Cramer's $V=.096$, and that they did not consider remarriage due to their religious or social beliefs and values, $\chi^{2}(1, N=1,352)=9.14, p<.01$, Cramer's $V=.082$, or old age or health, $\chi^{2}(1, N=1,352)=4.57, p<.05$, Cramer's $V=.058$.

\section{DISCUSSION}

One of the important findings of this study is the fact that the majority of respondents (67.4\%) stated that they would not consider remarriage. There was nevertheless a significant difference between respondents who were married and those previously married, with the latter being more likely to consider remarriage. We did not come across literature asking married participants whether they would consider remarrying and therefore we cannot compare our findings with previous research.

It was not surprising to note that the majority of respondents would not consider remarriage given that separation rates in Malta are relatively low: According to the last census carried out in Malta in 2011, only $8.12 \%$ of the total married population had separated, and another $1.01 \%$ had divorced (NSO, 2014). When we look at the statistics related to divorce and remarriage following the introduction of divorce legislation, we find that until December 31, 2013, 1,083 applications for divorce were filed in the Family Section of the Civil Court and 936 judgments granting divorce were handed down (E. Sciriha, Director and Registrar at the Civil Courts of Malta and the Tribunals Directorate, personal communication, November 4, 2014). Given that according to the 2011 census there were 15,987 separated people living in Malta (NSO, 2014), the figures for divorce are in fact low. So, too, is the figure for remarriages from October 1, 2011 through December 31, 2013 : This period saw a total of 49 remarriages involving Maltese nationals who had been previously divorced (M. Zerafa, Manager of the Population and Tourism Statistics Unit at the NSO, personal communication, December 2, 2014). Nevertheless caution must be exercised in interpreting these figures given that divorce was only legislated in 2011.

It is to be noted that remarriage rates in Malta could be affected by the cautious approach taken to securing a divorce, as is the case in Ireland (Lunn \& Fahey, 2011). This is because the conditions for divorce entail a waiting period of 4 years following separation as well as the guarantee of adequate maintenance. These prerequisites, which are similar to those approved by voters in the Irish divorce referendum of 1995, were also set out in the referendum question posed to Maltese voters. ${ }^{1}$

\footnotetext{
The English version of the question posed was "Do you agree with the introduction of the option of divorce in the case of a married couple who has been separated or has been living apart for at least
} 
Low remarriage rates could also be attributed to the spread of nonmarital cohabitation, as is the case in Hungary (Földházi, 2010). It is interesting to note that remarriage rates in European countries vary. Beier, Hofäcker, Marchese, and Rupp (2010) stated that northern European states showed increases of about 10 percentage points, whereas except for Portugal, which registered a moderate increase, southern European countries as well as Ireland showed very low increases or no differences.

Furthermore, recent research suggests that marital satisfaction in Malta is high (Abela, 2014), leading us to argue that most Maltese married couples have little intention to separate or divorce, and even less to remarry. From an attachment theory perspective (Hazan \& Shaver, 1987), one could argue that the bond married participants have with their spouse mitigated against their entertaining the thought of a possible divorce, let alone remarriage. Furthermore it is interesting to note that those married respondents who were in favor of remarriage were significantly more likely than previously married respondents to cite living in the company of someone as a reason for remarriage. This could be interpreted as a reflection of their need for connectedness.

Love topped the list of justifications for remarriage for both those who were married and those previously married. As expected, those previously married were significantly more likely to reconsider remarriage. The latter were also significantly more likely to consider remarriage to have rights and entitlements as well as for the sake of the children. The absence of legislation on divorce in Malta at the time the field work was carried out seemed to put respondents who were previously married at a disadvantage. Not only were they denied the right to remarry, but they were also denied the rights and entitlements that married couples enjoy as part of their legal covenant. Such respondents' vulnerabilities are further exacerbated by the absence of a cohabitation law in Malta. The National Commission for the Promotion of Equality (NCPE, 2014) has drafted a proposal to have a Bill on Cohabitation to set a legal basis that would regularize such relationships.

The distinct divide between the younger and the older generations with regard to the consideration of remarriage is also worth noting, with those under 40 being significantly more in favor of remarriage. This finding is in tune with research indicating that the proportion of individuals who remarry declines with age (Cruz, 2012). In the Maltese context, this distinction reflects other liberal attitudes regarding lifestyle choices between the older and younger generations, such as the fairly recent dramatic increase in births outside marriage (Abela, 2013). This trend could be understood as a turning point in Maltese society signaling a fast entry into the second demographic transition. The prevailing attitudes among the younger generation seem to be

four (4) years, and where there is no reasonable hope for reconciliation between the spouses, whilst adequate maintenance is guaranteed and the children are protected?" 
having a powerful influence on the older generation. In spite of the fact that the majority of our respondents did not consider remarriage-with $20.3 \%$ of these not considering it because of religious or social beliefs and valuesthe referendum result in favor of divorce might lead us to hypothesize that they were nevertheless in favor of granting the right to divorce to those who wanted it. Given the small size of our island, we live in a face-to-face community (rather than anonymously). Such close interactions could help us make sense of the attitudes of more conservative citizens. Having been in contact with other members in the community or indeed family members who are dear and close to them but who unlike them find themselves having to rebuild new relationships in their lives due to marriage breakdown, might have sensitized them to the need for the legislation of divorce.

In spite of the fact that this was a quantitative survey asking members of the general public a hypothetical question about remarriage, most of the findings tally with data on remarriers as well as with results of qualitative studies on the subject. For example, participants who were younger were more likely to consider remarriage; in addition, old age or health was the third most cited reason for not considering remarriage. Consistent with data on male remarriers reported earlier, participants with higher educational attainments and higher employment status were more likely to consider remarriage. Contrary to the main trend in the literature, however, women with a higher level of education and socioeconomic status were as likely as men to reconsider remarriage. This finding merits more in-depth investigation, as does the surprising finding that married men were no more likely to consider remarriage than married women, whereas previously married men were more likely to consider remarriage than previously married women. One possible hypothesis would be that men do not necessarily view remarriage as the ideal way forward when married but change their attitudes once they divorce.

The finding that parents were statistically less likely to consider remarriage than nonparents is similar to De Graaf and Kalmijn's (2003) statement that children generally reduce remarriage prospects. The fact that previously married persons without children were the most likely group to consider remarriage might be interpreted as their being more likely to consider remarrying to have children in marriage.

Interestingly, children's well-being was mentioned as a factor informing both arguments in favor of and against remarriage ( $8 \%$ and $5.8 \%$ of respondents, respectively), with women being significantly more likely to either favor or oppose remarriage for children's sake. Although we did not come across data comparing gender attitudes in this regard, these findings are in tune with Kavas's (2010) study in which some women spoke of their desire to have a complete family with a father figure for their children, whereas fear for their children's welfare was mentioned by others as a reason against remarriage. 
Different possible interpretations could account for the finding that parents whose children were all born within marriage were considerably less likely to be in favor of remarriage when compared to those who had children born out of marriage. In a similar vein to the argument that married respondents were less likely to entertain thoughts of remarriage due to the bond with their spouses, one could argue that in the case of those whose children were all born within marriage, the wish to preserve the bond with the other parent of the children mitigated against entertaining thoughts of remarriage. Parents of children born outside marriage might have perceived remarriage as beneficial in that it would formalize their current or future relationship with a partner and make it legally binding, thus protecting their rights and entitlements and those of their children. Furthermore, remarriage might also have been perceived by these parents as beneficial in the sense of regulating the family form and thus restoring balance and normalcy as reported by Määttä and Uusiautti (2012), especially in the case of those whose current partner was the parent of the children.

The two most common reasons given by respondents who considered remarriage, namely, love and living in the company of someone tally with the qualitative findings of Kavas (2010) and Schmiege et al. (2001), who carried out their research with female participants in Turkey and the United States, respectively. Furthermore, the findings that female respondents were more likely to consider remarriage for love and for the sake of the children are also in tune with Kavas's (2010) arguments that women's emotional needs superseded other needs and that love and the desire to have a complete family were two reasons given for the decision to remarry.

Contextual influences relating to the timing of the divorce referendum and public debates during the run-up to it could account for findings that some respondents cited because it's a right and to have rights and entitlements as reasons for remarriage, which are noticeably absent in foreign literature. As already discussed, the absence of cohabitation law in Malta could have also spurred respondents to cite having rights and entitlements as a reason for remarriage.

Interestingly the most cited reason for not considering remarriage was religious or social beliefs and values, which reflects the fact that religious values are still prevalent in Maltese society especially in the older generation. The next most cited reason, not to relive past bad experiences, tallies with the findings of Kavas (2010), Määttä and Uusiautti (2012), and Steenbergen Richmond (2000), who reported on participants' fears of repeating past mistakes and making themselves vulnerable to hurt. Interestingly, female respondents were significantly more likely than male respondents not to reconsider remarriage not to relive past bad experiences. This, too, highlights the importance given to emotional expression in the female population. On the other hand, male respondents were significantly more likely 
than female respondents not to reconsider remarriage due to old age or health, a finding that merits further investigation.

Having experienced emotional pain or trauma could account for the fact that previously married respondents were significantly more likely than married respondents not to consider remarriage not to relive past bad experiences, because they see no particular need, and do not want to have any commitment. However, the fact that they were less likely than married respondents to state that there should be only one marriage, that they did not consider remarriage due to religious or social beliefs and values or due to old age or health, could be interpreted as their leaving the door open to the possibility of remarriage. They would thus give themselves the possibility to reedit their story, a concept discussed by Byng-Hall (1995), rather than being organized by normative societal values including ageism. Another reason for old age or health being cited less as a reason against remarriage by previously married respondents could be the fact that previously married respondents were significantly younger than married respondents.

\section{LIMITATION OF THE STUDY AND SUGGESTIONS FOR FURTHER RESEARCH}

The key limitation of the study was the hypothetical nature of the question asked. Respondents' attitudes might change when they actually go through divorce. Choices and constraints regarding remarriage are not only likely to be influenced by previous marital history as argued by Davidson (2002), but are also likely to be influenced by the disposition to be open to change. An important theme that emerged from some qualitative studies is that some participants did not date with the intention of finding a marriage partner, at least in the beginning (Watson et al., 2010). In this respect, our suggestion for further research would be to study the actual population of Maltese divorcees as well as those who remarry.

\section{IMPLICATIONS FOR POLICY}

This study was unique given that it was driven by a contextual event, the referendum on whether to introduce divorce legislation in Malta and our intention to extend reflection on attitudes toward remarriage in our particular context. Responses brought to light an important implication for Malta, namely the lack of protection accorded to couples in long-term relationships outside marriage. Noack, Bernhardt, and Wiik (2014) argued that cohabiting couples have never lobbied to be treated like married people. The absence of legislation on divorce and the legal right to remarry led many of our respondents to harbor the need to have such legislation in place to have their 
rights and entitlements, including those of their children, protected. In Malta, where cohabitation has been recorded among 5\% of the adult population (NSO, 2014), the legal protection of the family is still exclusive to marriage. We are in agreement with NCPE that cohabitation should also provide similar rights and entitlements as is the case in countries with high cohabiting rates, which tend to have the best statutory regulation of unmarried cohabitation (Noack et al., 2014). This makes a lot of sense not only from a minority rights perspective, but also in the context of Malta's entry into the second demographic transition and an ever increasing prevalence of different family forms (Abela, 2013).

\section{ACKNOWLEDGMENTS}

We are grateful to the National Statistics Office for their collaboration in this project by way of carrying out the CATI survey.

\section{REFERENCES}

Abela, A. (2013). Malta. In R. E. Emery (Ed.), Cultural sociology of divorce: An encyclopedia (Vol. 2, pp. 748-753). Thousand Oaks, CA: Sage.

Abela, A. (2014, March). Changing dynamics in Maltese marriages. Paper presented at the 1st European Conference on Systemic Research in Therapy, Education and Organizational Development: Linking Systemic Practice and Systemic Research, Heidelberg, Germany.

Ahituv, A., \& Lerman, R. (2004). Job turnover, wage rates, and marital stability: How are they related? Retrieved from http://www.urban.org/publications/411148. html

Beier, L., Hofäcker, D., Marchese, E., \& Rupp, M. (2010, April). Existential Field 1: Family structures \& family forms - An overview of major trends and developments (Working Report). Retrieved from https://eldorado.tu-dortmund.de/ handle/2003/27689

Bronfenbrenner, U. (1994). Ecological models of human development. In T. Husén \& T. N. Postlethwaite (Eds.), International encyclopedia of education (2nd ed., Vol. 3, pp. 1643-1647). Oxford, UK: Elsevier.

Byng-Hall, J. (1995). Rewriting family scripts: Improvisation and systems change. New York, NY: Guilford.

Bzostek, S. H., McLanahan, S. S., \& Carlson, M. J. (2012). Mothers' repartnering after a nonmarital birth. Social Forces, 90, 817-841. doi:10.1093/sf/sos005

Cruz, J. (2012). Remarriage rate in the U.S., 2010 (FP-12-14). Retrieved from http:// ncfmr.bgsu.edu/pdf/family_profiles/file114853.pdf

Davidson, K. (2002). Gender differences in new partnership choices and constraints for older widows and widowers. Ageing International, 27(4), 43-60. doi:10.1007/s12126-002-1014-0 
De Graaf, P. M., \& Kalmijn, M. (2003). Alternative routes in the remarriage market: Competing-risk anayses of union formation after divorce. Social Forces, 81, 1459-1498. doi:10.1353/sof.2003.0052

de Jong Gierveld, J. (2004). Remarriage, unmarried cohabitation, living apart together: Partner relationships following bereavement or divorce. Journal of Marriage and Family, 66, 236-243.

Földházi, E. (2010). New partnership after first divorce-An event history analysis. Demográfia, 53(5), 78-101.

Galea, P. (2012). Cohabitation, single parenting, extended-family parenting, and the role of kinship and religion. International Journal of the Jurisprudence of the Family, 2, 163-177.

Hazan, C., \& Shaver, P. (1987). Romantic love conceptualized as an attachment process. Journal of Personality and Social Psychology, 52, 511-524.

Kavas, S. (2010). Post divorce experience of highly educated and professional women (Unpublished doctoral thesis). Middle East Technical University.

Kim, J. (2011). Should I marry again? Retrieved from http://www.kdi.re.kr/data/ download/attach/9273_04_Kim.pdf

Lunn, P., \& Fahey, T. (2011). Housebolds and family structures in Ireland: A detailed statistical analysis of Census 2006 (A Report for the Family Support Agency). Retrieved from http://www.esri.ie/UserFiles/publications/ SUB002/BKMNEXT202.pdf

Määttä, K., \& Uusiautti, S. (2012). Changing identities: Finnish divorcees' perceptions of a new marriage. Journal of Divorce \& Remarriage, 53, 515-532. doi:10.1080/10502556.2012.682906

McGoldrick, M., \& Carter, B. (2013). Families transformed by the divorce cycle: Reconstituted, multinuclear, recoupled, and remarried families. In M. McGoldrick, B. Carter, \& N. Garcia-Preto (Eds.), The expanded family life cycle: Individual, family, and social perspectives (4th ed., pp. 317-335). Boston, MA: Allyn \& Bacon.

Miner, E. J., \& Shackelford, T. K. (2010). Mate attraction, retention and expulsion. Psicothema, 22(1), 9-14.

National Commission for the Promotion of Equality. (2014). Annual report 2013. Retrieved from http://socialdialogue.gov.mt/en/ncpe/documents/our_ publications_and_resources/annual_reports/ncpe\%20annual\%20report $\% 2010$. pdf

National Statistics Office. (2014). Census of population and housing 2011: Final report. Retrieved from http://www.nso.gov.mt/site/page.aspx?pageid=588

Noack, T., Bernhardt, E., \& Wiik, K. A. (2014). Cohabitation or marriage? Contemporary living arrangements in the West. In A. Abela \& J. Walker (Eds.), Contemporary issues in family studies: Global perspectives on partnerships, parenting and support in a changing world (pp. 16-30). Chichester, UK: Wiley-Blackwell.

Rose, V. L., \& Price-Bonham, S. (1973). Divorce adjustment: A woman's problem. The Family Coordinator, 22, 291-297.

Schmiege, C. J., Richards, L. N., \& Zvonkovic, A. M. (2001). Remarriage: For love or money? Journal of Divorce \& Remarriage, 36(1-2), 123-140. doi:10.1300/ J087v36n01_07 
Steenbergen Richmond, L. (2000). Courtship following divorce: A grounded theory approach (Unpublished doctoral dissertation). University of Arizona.

Watson, W. K., Bell, N. J., \& Stelle, C. (2010). Women narrate later life remarriage: Negotiating the cultural to create the personal. Journal of Aging Studies, 24, 302-312. doi:10.1016/j.jaging.2010.07.002

Wilcox, W. B., \& Nock, S. L. (2006). What's love got to do with it? Equality, equity, commitment and women's marital quality. Social Forces, 84, 1321-1345. doi: $10.1353 /$ sof. 2006.0076 